\title{
Polymerase chain reaction for detection of Chlamydia trachomatis in conjunctival swabs
}

\author{
Elfath M Elnifro, Christopher C Storey, David J Morris, Andrew B Tullo
}

\begin{abstract}
Aims/background-Ocular Chlamydia trachomatis infection in the west occurs as ophthalmia neonatorum, acquired from the mother, or adult paratrachoma which is also associated with current genital tract infection. Accurate rapid laboratory diagnosis facilitates management, but the relative merits of antigen detection or DNA amplification tests are unresolved.

Methods-A polymerase chain reaction (PCR) test was developed which amplified part of the plasmid shared by all the serovars of $C$ trachomatis. Conjunctival swabs were tested using an in house immune dot-blot test (IDBT) for chlamydial lipopolysaccharide antigen, a commercial direct fluorescent antibody (DFA) test for chlamydial elementary bodies, and the PCR (DNA extracted using guanidinium lysis buffer).
\end{abstract}

Results-The PCR achieved a detection limit of 100 plasmid copies (10 elementary bodies). In a combined retrospective and prospective clinical evaluation, the PCR and IDBT gave identical results with 21 positive and 57 negative eye swabs. However, interpretation of the DFA test required meticulous examination of the stained smear, sometimes by two microscopists.

Conclusions-The PCR is likely to play an increasing role in the diagnosis of ocular $C$ trachomatis infection because of its excellent sensitivity and specificity.

Division of Virology Department of Pathological Sciences, University of

Manchester

E M Elnifro

D J Morris

Clinical Virology

Laboratory,

Manchester Royal

Infirmary, Manchester

C S Storey

D J Morris

Royal Eye Hospital, Manchester

A B Tullo

Correspondence to: Mr Elfath M Elnifro, Clinical Virology, 3rd Floor, Clinical Sciences Building, Manchester Royal Infirmary, Oxford Road, Manchester, M13 9WL.

Accepted for publication 3 March 1997 divion conjunctivitis, also called paratrachoma, in sexually active young adults following transfer of bacteria from the genitalia to the eye; and ophthalmia neonatorum acquired from the mother. ${ }^{1}$ Only the latter two conditions are seen in developed countries such as the UK. Paratrachoma begins as follicular conjunctivitis, and if not treated persists though does not lead to blindness. ${ }^{1}$ It can, however, be confused clinically with other causes of chronic conjunctivitis. A minimum of $70 \%$ of women (and possibly all) with chlamydial conjunctivitis are estimated to have genital $C$ trachomatis infection, mostly asymptomatic but possibly associated with diminished fertility. ${ }^{2-5}$ Ophthalmia neonatorum presents as swelling of the eyelid, and progresses to purulent inflammation of the conjunctiva. If untreated, the disease can persist for up to 1 year, and, though usually self limiting, may result in blindness due to secondary bacterial infections. Infected neonates often develop pharyngitis, otitis media, and pneumonia due to chlamydia. ${ }^{2}$ Both the mother and the baby should be treated. ${ }^{2}$

Accurate rapid laboratory diagnosis is crucial to the successful management of adult and neonatal chlamydial conjunctivitis. ${ }^{6-13}$ Culture of eye swabs on cycloheximide treated McCoy cells was the 'gold standard' technique, though, owing to its slowness, complexity, and susceptibility to microbial overgrowth and cell toxicity, it has been largely replaced by the direct fluorescent antibody (DFA) test for elementary bodies ${ }^{14}$ and/or enzyme immunoassay (EIA). ${ }^{15}$ The DFA test shows a sensitivity of $95-100 \%$ in comparison with culture in neonatal eye infections. ${ }^{14}$ None the less, laborious microscopic examination of each specimen by highly skilled and experienced personnel is recommended, ${ }^{16}$ and the assay is only suitable for the examination of small numbers of specimens. In contrast, EIAs are ideal for testing large numbers of samples, achieve sensitivities of $90 \%$ in comparison with culture, but may be less sensitive than DFA and are prone to give false positive reactions. ${ }^{14}{ }^{15}$ In this laboratory we use a novel, simple, immune dot-blot test (IDBT) for detection of chlamydial lipopolysaccharide (LPS) antigen which gives a sensitivity of $92 \%$ with genital swabs ${ }^{17}$ and twice as many positive results with eye swabs ${ }^{18}$ in comparison with culture. With the advent of the polymerase chain reaction (PCR), assays for chlamydia more sensitive than culture or even DFA have been developed. ${ }^{19}$ In this study, we compare DFA, IDBT, and the PCR for the diagnosis of ocular $C$ trachomatis infection in a combined retrospective and prospective study.

\section{Materials and methods}

CLINICAL SAMPLES

Cotton tipped conjunctival swabs for investigation of suspected chlamydial conjunctivitis were collected in $1 \mathrm{ml}$ of sucrose phosphate (2SP) transport medium ( $8 \mathrm{mM} \mathrm{KH}_{2} \mathrm{PO}_{4}, 12$ $\mathrm{mM} \mathrm{K} \mathrm{HPO}_{4}$, and $0.2 \mathrm{M}$ sucrose) supplemented with antibiotics (amphotericin B 2.5 $\mu \mathrm{g} / \mathrm{ml}$, streptomycin $50 \mu \mathrm{l} / \mathrm{ml}$, and vancomycin $\left.100 \mu \mathrm{g} / \mathrm{ml}^{20}\right)$. Each sample (100 $\mu$ l volume) was prepared for PCR testing by 10 minutes' incubation at room temperature with $400 \mu \mathrm{l}$ guanidinium isothiocyanate lysis buffer (4 M 
guanidinium isothiocyanate, $0.5 \% \quad N$-lauryl Sarcosine, $1 \mathrm{mM}$ dithiothreitol, $25 \mathrm{mM}$ sodium citrate, $20 \mu \mathrm{g}$ glycogen) and then precipitation with $125 \mu$ cold $100 \%$ isopropanol. The samples were centrifuged for $10 \mathrm{~min}$ utes at $14000 \mathrm{~g}$ at $4^{\circ} \mathrm{C}$. The isopropanol was removed and the pellet washed by the addition of $250 \mu 170 \%$ ethanol. The samples were centrifuged as above, the ethanol was removed and the dried pellet dissolved in $10 \mu \mathrm{l}$ sterile double distilled water. ${ }^{21}$

CONTROL DNA SAMPLES

Crude DNA extracts from turbid suspensions of Staphylococcus aureus, Pseudomonas aeruginosa, Escherichia coli, Candida albicans organisms, cycloheximide treated sonicated McCoy cells infected with $C$ trachomatis serotype $\mathrm{E}$ (T181) $\left(4 \times 10^{6}\right.$ inclusion forming units $\left./ \mathrm{ml}\right)$, and $10^{5}$ cells infected with herpes simplex virus (HSV) type 1 or adenovirus type 2 were prepared by centrifugation of a $100 \mu \mathrm{l}$ sample at $13000 \mathrm{~g}$, and incubation of the resuspended pellet in proteinase $\mathrm{K}(250 \mu \mathrm{g} / \mathrm{ml})$ for 3 hours at $56^{\circ} \mathrm{C}$ and then $95^{\circ} \mathrm{C}$ for 30 minutes to inactivate the enzyme. Cloned caesium chloride purified $C$ trachomatis L2 plasmid DNA $(\mathrm{pCtL} 2)^{22}$ was used as the positive control in the PCR.

IMMUNE DOT-BLOT TEST

Conjunctival swab transport medium $(0.4 \mathrm{ml})$ was treated with $250 \mu \mathrm{g} / \mathrm{ml}$ proteinase $\mathrm{K}$ for 30 minutes at $56^{\circ} \mathrm{C}$ principally to digest staphylococcal protein $\mathrm{A}$, a cause of false positive reactions in the IDBT. ${ }^{17}$ The enzyme was inactivated at $95^{\circ} \mathrm{C}$ for 15 minutes, and the sample added to a nitrocellulose membrane in a dot-blot manifold. The blotted antigen was detected with J12, a monoclonal antibody which reacts with a Chlamydia specific epitope on the LPS, ${ }^{23}$ radiolabelled with ${ }^{125} \mathrm{I}$ using the method of Hunter et al. ${ }^{24}$ Each 96 well membrane was reacted with $33 \mathrm{KBq}$ of ${ }^{125} \mathrm{I}$ labelled antibody and bound antibody detected by autoradiography. The sample was considered positive if the intensity of the darkened circle on the $x$ ray film exceeded that formed by 100 inclusion forming units of $C$ trachomatis serotype E. ${ }^{17}$ This test was performed on the open bench in our multiuser diagnostic laboratory.

POLYMERASE CHAIN REACTION

Two buffers were used successively in the PCR. Buffer 1 gave final concentrations in the reaction mixture of $67 \mathrm{mM}$ TRIS-HCl, $16 \mathrm{mM}$ $\left(\mathrm{NH}_{4}\right)_{2} \mathrm{SO}_{4}, 4 \mathrm{mM} \mathrm{MgCl}, 1 \mathrm{mg} / \mathrm{ml}$ bovine serum albumin, $0.072 \% \mathrm{v} / \mathrm{v} 2$-mercaptoethanol, $200 \mu \mathrm{M}$ each deoxynucleoside triphosphate (dNTP), 1 unit (U) Taq DNA polymerase (Boehringer, Mannheim, Germany), and 0.2 $\mu \mathrm{M}$ each primer. ${ }^{26}$ The final concentrations achieved with buffer 2 were $10 \mathrm{mM}$ TRIS- $\mathrm{HCl}$, $50 \mathrm{mM} \mathrm{KCl}, 1.5 \mathrm{mM} \mathrm{MgCl}, 200 \mu \mathrm{M}$ each dNTP, 15 U Taq DNA polymerase and $0.1 \mu \mathrm{M}$ each primer. ${ }^{17}$ The primers $\mathrm{CtC}$ (5'-AAG ATACGTGAATTCTTAAGTT-CGGTC-3') and $\mathrm{CtD}$ (5'-TAATTGATCCA-AACT CTGACTTTCCTC-3') hybridise to regions
5331-5357 and 5788-5762 on the chlamydial plasmid $^{25}$ and amplify a 457 base pair fragment. ${ }^{26}$ Each $100 \mu \mathrm{l}$ reaction mixture included $10 \mu \mathrm{l}$ DNA extract, sterile distilled water (SDW) as a negative control, or SDW containing 1000 copies pCt L2 as a positive control. The thermal cycles were as previously described $^{26}$; DNA was amplified by one cycle of $94^{\circ} \mathrm{C}$ for 7 minutes, $55^{\circ} \mathrm{C}$ for 1 minute, and $72^{\circ} \mathrm{C}$ for 1 minute followed by 49 cycles of $94^{\circ} \mathrm{C}$ for $1 \frac{1 / 2}{}$ minutes, $55^{\circ} \mathrm{C}$ for 1 minute, and $72^{\circ} \mathrm{C}$ for $1 \frac{1 / 2}{2}$ minutes. The PCR products were analysed by electrophoresis through $1 \%$ agarose gels in parallel with a $1 \mathrm{~kb}$ ladder (Gibco-BRL, Paisley, Scotland).

DIRECT FLUORESCENT ANTIBODY TEST

The specimen $(100 \mu \mathrm{l})$ was centrifuged at $13000 \mathrm{~g}$ for 5 minutes and the resultant pellet resuspended in 10-20 $\mu$ l phosphate buffered saline (PBS). Five $\mu$ l of the suspension were placed onto each of two wells of a multiwell glass slide, air dried, and fixed in methanol. After staining with a minimum volume of fluorescein isothiocyanate conjugated monoclonal antibody to the chlamydial major outer membrane protein (Syva, San Jose, USA) by incubation at $37^{\circ} \mathrm{C}$ for 30 minutes, and then washing with PBS, the smears were mounted in PBS/glycerol (50/50) and examined by ultraviolet microscopy.

\section{Results}

SENSITIVITY AND SPECIFICITY OF THE PCR With buffer 1, the PCR detection limit was 1000 copies of $C$ trachomatis plasmid DNA or 400 inclusion forming units of $C$ trachomatis. Use of buffer 2 increased the sensitivity 10 -fold to 100 copies of plasmid DNA. All subsequent DNA amplifications were done using buffer 2 . No $\mathrm{CtC} / \mathrm{CtD}$ amplification product was generated with DNA extracted from $S$ aureus, $P$ aeruginosa, $E$ coli, $C$ albicans, HSV type 1, or adenovirus type 2 .

\section{RETROSPECTIVE EVALUATION}

Thirty seven eye swabs in transport medium which had been stored at $-70^{\circ} \mathrm{C}$ for up to 1 year following completion of the IDBT were examined using PCR. Thirty of these swabs were also tested by DFA test. All assays were done blind-that is, PCR testing without knowledge of IDBT results and DFA testing without knowledge of PCR or IDBT results. Sixteen samples were positive for chlamydia in both the IDBT and the PCR, and 21 specimens were negative in these two tests (for example of PCR results, see Fig 1). Identical results were obtained in the DFA assay for all 16 of the positive and 14 of the negative conjunctival swabs.

Interpretation of the DFA test required examination of the smears by two microscopists, both to identify correctly all IDBT positive and negative samples (four were initially misclassified as negative by one observer) and to determine the consensus result when initial screening was inconclusive (Table 1). 


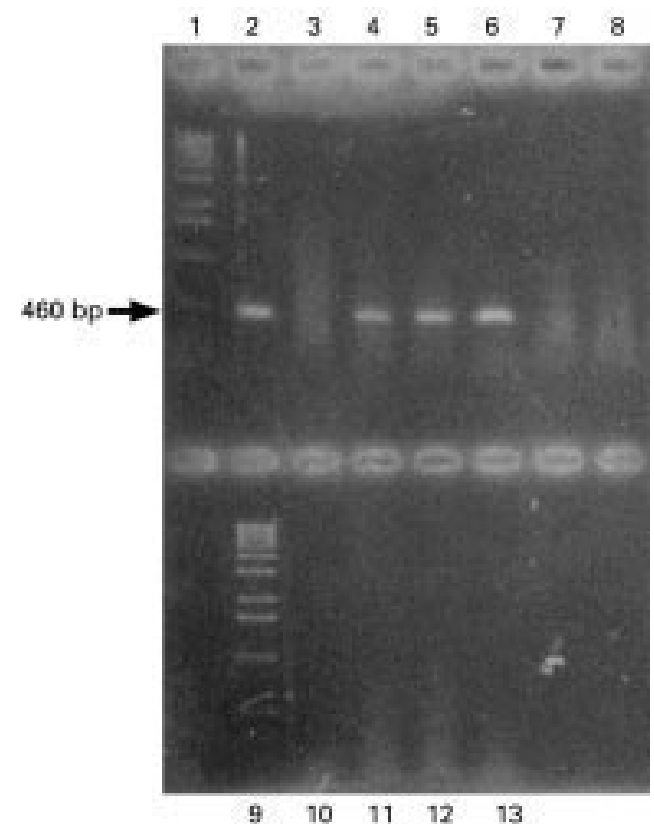

Figure 1 Polymerase chain reaction using Chlamydia trachomatis plasmid primers $C t C$ and $C t D$ on conjunctival swab DNA extracts. Lanes 1 and 9, $1 \mathrm{~kb}$ ladder (Gibco-BRL); lane 2, positive control (1000 copies pCtL2); lane 3, negative control (sterile distilled water); lanes 4-6, immune dot-blot test (IDBT) positive eye swabs; lanes 7,8 , and 10, IDBT negative eye swabs; lanes 11-13, TRIS-EDTA, a control for cross contamination.

PROSPECTIVE EVALUATION

Forty one conjunctival swabs were tested prospectively on the day of receipt by IDBT and within 1 week by PCR; five were positive and 36 negative in both assays. Combination of the data from the retrospective and prospective evaluations established that the PCR achieved a sensitivity (21/21), a specificity (57/57), a positive predictive value $(21 / 21)$, and a negative predictive value $(57 / 57)$ that were all $100 \%$ if the IDBT result was considered accurate.

\section{Discussion}

Our data confirmed the interpretative difficulties previously documented with the chlamydial DFA test. ${ }^{16}$ Only meticulous time consuming scrutiny of the smear, sometimes by two microscopists, guaranteed accurate results in this test.

In our laboratory, the IDBT replaced culture in cycloheximide treated McCoy cells for diagnosis of ocular $C$ trachomatis infection because the IBDT was more sensitive than culture with conjunctival swabs. ${ }^{18}$ The identical dot-blot,

Table 1 Results of direct fluorescent antibody (DFA) test on 30 conjunctival swabs read by two microscopists

\begin{tabular}{lllll}
\hline \multirow{5}{*}{ Sample No } & \multicolumn{2}{l}{ DFA test result } & & \\
\cline { 2 - 4 } & Observer 1 & Observer 2 & Consensus & IDBT and PCR \\
\hline $1-12$ & + & + & + & + \\
$13-20$ & - & - & - & - \\
21,22 & + & - & + & + \\
23,24 & $+/-$ & - & + & + \\
$25-28$ & $+/-$ & $+/-$ & - & - \\
29 & $+/-$ & $+/-$ & - & - \\
30 & - & & &
\end{tabular}

IDBT = immune dot-blot test; $\mathrm{PCR}=$ polymerase chain reaction.

+ Positive; - negative; +/- equivocal.
DFA, and PCR results obtained in this study proved the excellent sensitivity and specificity of our in house test for chlamydial LPS. This specificity was achieved following introduction of sample pretreatment with proteinase $\mathrm{K}$, which destroyed staphylococcal protein A, a known cause of false positive results in the assay. ${ }^{17}$ Also, proteinase $\mathrm{K}$ treatment possibly released LPS from contaminating proteins to make the antibody binding sites more accessible and the test more sensitive. Our IDBT for adenovirus hexon protein precluded specimen pretreatment with proteinase $\mathrm{K}$, and gave an unacceptably high false positive rate $^{27}$ and a lower sensitivity than adenovirus PCR when testing eye swabs. ${ }^{28}$ Commercial EIAs for chlamydia give false positive readings, ${ }^{14} 15$ perhaps because proteinase $\mathrm{K}$ digestion of contaminating proteins cannot be included.

The difference in the detection limit of the PCR using buffer 1 for $C$ trachomatis (400 inclusion forming units) or purified plasmid pCtL2 (1000 copies) reflected the 10 plasmid copies found in each chlamydial elementary and reticulate body. ${ }^{22}{ }^{29}$ This high copy number and the presence of the plasmid in all serovars of $C$ trachomatis $^{22}$ led us to choose plasmid rather than chromosomal DNA as the molecular target for our PCR. Amplification of chlamydial plasmid rather than major outer membrane protein gene sequences enhanced the sensitivity of detection of cultured organisms by a factor of $4 .{ }^{19}$ A possible disadvantage of chlamydial plasmid based amplification is the potential occurrence of plasmid-less strains of $C$ trachomatis which could result in a false negative result by a PCR with a plasmid target. ${ }^{30}{ }^{31}$ However, despite much speculation strains of $C$ trachomatis which do not contain plasmids have never been isolated and cultured and if they do exist they probably occur at a very low frequency. Switching to a simple buffer (buffer 2) increased the sensitivity to that achieved previously only with the addition of Southern blot hybridisation for the identification of PCR products. ${ }^{26}$

The PCR sensitivity achieved in this analysis (100 plasmid copies, equivalent to 10 elementary bodies) was 10-fold lower than that reported previously using different primers also targeting the chlamydial plasmid. ${ }^{32} \mathrm{Nu}-$ cleic acid amplification using the latter oligonucleotides gave false positive results as a result of airborne contamination which was only eliminated following the development of a closed system for carrying out the PCR. ${ }^{32}$ In contrast, our PCR gave no false positive results despite the handling of specimens on the open bench during the IDBT. Published PCRs for the chlamydial plasmid achieved higher diagnostic sensitivity for ocular infection than EIA, culture, or the DFA test. ${ }^{345}$ The failure to document differences in performance between the latter assay, the IDBT, and our PCR for the $C$ trachomatis plasmid probably reflected the similarity of the detection limits in the two in house tests (100 inclusion forming units or 10 elementary bodies, respectively).

In our laboratory, continued use of the IDBT for initial screening of eye swabs for $C$ 
trachomatis infection was validated. In laboratories without access to the IDBT, the DFA test could be recommended only if small numbers of specimens were submitted and all were examined by skilled and experienced microscopists. Though commercial EIAs have the advantages of low cost, suitability for testing large numbers of specimens, and availability of reagents subject to external quality control, the false negative and false positive results generated are a serious disadvantage when effective treatment of chlamydial eye disease is available, and failure to treat could lead to chronic conjunctivitis in babies or infertility in adult women. ${ }^{2}$ Also, inaccurate diagnosis of $C$ trachomatis infection in a patient being investigated for conjunctivitis and not a sexually transmitted disease could lead to litigation. The excellent performance of the chlamydial plasmid PCR none the less reinforced the potential role of DNA amplification assays for diagnosis of ocular chlamydial infection. Nucleic acid contamination of specimens during routine diagnostic testing was not detected. The commercial Roche Diagnostic Systems $C$ trachomatis plasmid PCR, which gave similar results to the DNA amplification assay described here with oropharyngeal swabs, ${ }^{26}$ proved only marginally less sensitive than culture with conjunctival swabs, ${ }^{35}$ and includes a proprietary system designed to avoid false positive results due to contaminating amplicons from previous PCRs. Where the IDBT is not available, the arguments in favour of using the in house or commercial PCR for detection of $C$ trachomatis in eye swabs appear to be strong. The successful use in our $C$ trachomatis plasmid PCR of the simple buffer also employed in sensitive single target adenovirus ${ }^{28}$ and duplex adenovirus-HSV PCRs $^{36}$ could mean that multiplex PCRs may be feasible for the diagnosis of ocular surface infections where Chlamydia, adenovirus, and HSV are all considered possible causative agents.

1 Schachter J. Chlamydiae. In: Davis BD, Dulbecco R, Eisen HN, Ginsberg HS, eds. Microbiology. New York: J B Lippincott, 1990: 699-706.

2 Dunlop EMC. Venereal disease. Chlamydial genital infection and its complications. Br f Hosp Med 1983;29:6-11.

3 Vaughan-Jackson JD, Dunlop EM, Darougar S, Dwyer RS, Jones BR. Results of tests for Chlamydia in patients suffering from acute Reiter's disease compared with results of tests of the genital tract and rectum in patients with ocular infection due to TRIC agent. Br F Vener Dis 1972;48:44551.

4 Postema EJ, Remeijer L, Van der Meijden WI. Epidemiology of genital chlamydial infections in patients with chlamydial conjunctivitis; a retrospective study. Genitourin Med 1996;72:203-5.

5 Garland SM, Malatt A, Tabrizis S, Grando D, Lees MI, Andrew $\mathrm{JH}$, et al. Chlamydia trachomatis conjunctivitis prevelance and association with genital tract infection. Med f Aust 1995;162:363-6.

6 Darougar S, Monnickendam MA, Woodland RM. Management and prevention of ocular viral and chlamydial infection. CRC Crit Rev Microbiol 1989;16:369-418.

7 Taylor HR, Fitch CP, Murillo-Lopez F, Rapoza P. The diagnosis and treatment of chlamydial conjunctivitis. In Ophthalmol 1988;12:95-9.

8 Dawson CR. Follicular conjunctivitis. In: Wilson LA, ed. External diseases of the eye. New York: Harper and Row, 1979:57-75.

9 Darougar S, Woodland RM, Walpita P. Value and cost effectiveness of double culture tests for diagnosis of ocular viral and chlamydial infections. Br f Ophthalmol 1987;71:673-5.

10 Raos K, Madhavan HN, Padmanabhan P, Lakshmi S, Natarajan K, Garg D. Ocular chlamydial infections; clinicomicrobiological correlation. Cornea 1996;15:62-5.
11 Scott BD, Fortenberry JD. Postgonococcal conjunctivitis due to Chlamydia trachomatis. Sex Transm Dis 1986;13:1723.

12 Møler BR. Post-gonococcal conjunctivitis caused by Chlamydia trachomatis. Case report. Br F Vener Dis 1983;59: 109-10.

13 Ronnerstam R, Persson K, Hansson H, Renmarker K. Prevalance of chlamydial eye infection in patients attending an eye clinic, a VD clinic, and in healthy persons. Br f Ophthalmol 1985;69:385-8.

14 Stamm WE. Laboratory diagnosis of chlamydial infection. In: Bowie WR, Caldwell HD, Jones RP, Mardh PA, Ridgway GL, Schachter J, et al, eds. Chlamydial infections. Cambridge: Cambridge University Press, 1990:459-70

15 Schachter J. Diagnosis of Chlamydia trachomatis infection. In: Orfila J, Byrne GI, Chernesky MA, Grayston JT, Jones RB, Ridgway GL, et al, eds. Chlamydial infections. Bologna: Societa Editrice Esculapio, 1994: 93-302.

$16 \mathrm{~Eb}$ F, Orfila J. Rapid direct immunological procedures. In: La Placa M, Cevenini R, Donati M, Moroni A, Rumpianesi F, Sambri V, eds. Proceedings of the European Society of Chlamydia Research. Bologna: Societa Editrice Esculapio, 1988:223-6.

17 Mearns G, Richmond SJ, Storey CC. Sensitive immune dot-blot test for the diagnosis of Chlamydia trachomatis infection. F Clin Microbiol 1988;26:1810-3.

18 Bishop PN, Tullo AB, Killough R, Richmond SJ. An immune dot-blot test for the diagnosis of ocular infection with Chlamydia trachomatis. Eye 1991;5:305-8.

19 Ossewaarde JM, Rieffe M, Rozenberg-Arska M, Ossenkoppele PM, Nawrocki RP, Van Loon AM. Development and clinical evaluation of a polymerase chain reaction test for detection of $C$ trachomatis. F Clin Microbiol 1992;30:21228.

20 Spencer WN, Johnson FWA. Simple transport medium for the isolation of Chlamydia psittaci from clinical material. Vet Rec 1983;113:535-6.

21 Casas I, Powell L, Klapper PE, Cleator GM. New method for the extraction of viral RNA and DNA from cerebrospinal fluid for use in the polymerase chain reaction assay. $\mathcal{F}$ Virol Methods 1995;53:25-36.

22 Palmer L, Falkow S. A common plasmid of Chlamydia trachomatis. Plasmid 1986;16:52-62.

23 Thornley MJ, Zanze SE, Byrne MD, Lusher M, Evans RT. Properties of monoclonal antibodies to the genus-specific antigen of Chlamydia and their use for detection by reverse passive haemagglutination. F Gen Microbiol 1985;131:7-15.

24 Hunter WM, Greenwood FC, Glover JS. The preparation of ${ }^{131}$ I-labelled human growth hormone of high specific activity. Biochem f 1963;89:114-23.

25 Comanducci M, Ricci S, Ratti G. The structure of a plasmid of Chlamydia trachomatis believed to be required for growth within mammalian cells. Molecul Microbiol 1988;2:531-8.

26 Jebakumar SPR, Storey C, Lusher M, Nelson J, Goorney B, Haye KR. Value of screening for oro-pharyngeal Chlamydia trachomatis infection. f Clin Pathol 1995;48:658-61.

27 Morris DJ, Klapper PE, Killough R, Bailey AS, Nelson J, Tullo AB. Prospective study of adenovirus antigen detection in eye swabs by radioimmune dot-blot. Eye 1995; 9:629-32.

28 Morris DJ, Bailey AS, Cooper RJ, Turner PC, Jackson R, Corbitt G, et al. Polymerase chain reaction for rapid detection of ocular adenovirus infection. $\mathcal{f}$ Med Virol 1995;46: 126-32.

29 Tam JE, Davis CH, Tresher RJ, Wyrick PB. Location of the origin of replication for the $7.5-\mathrm{kb}$ Chlamydia trachomatis plasmid. Plasmid 1992;16:231-6.

30 Peterson EM, Markoff BA, Schachter J, Masa LM, The 7.5 $\mathrm{Kb}$ plasmid present in Chlamydia trachomatis is not essential for the growth of this microorganism. Plasmid 1990;23:144-8

31 Qi an, Radcliffe G, Vassallo R, Buxton D, O’Brien W, Pelletier DA, et al. Infection with a plasmid-free variant Chlamydia related to Chlamydia trachomatis identified by using multiple assays for nucleic acid detection. $\mathcal{F}$ Clin Microbiol 1992;30:2814-21.

32 Ostergaard L, Birklund S, Christiansen G. Use of polymerase chain reaction for detection of Chlamydia trachomatis. $\mathcal{F}$ Clin Microbiol 1990;28:1254-60.

33 Talley AR, Garcia-Ferrer F, Laycock KA, Loeffelholz M, Pepose JS. The use of polymerase chain reaction for the detection of chlamydial keratoconjunctivitis. Am f Ophthalmol 1992;114:685-92.

34 Kessler HH, Pierer K, Stuenzner D, Aver-Grumbach P, Haller E, Marth E. Rapid detection of Chlamydia trachomatis in conjunctival, pharyngeal, and urethral specimens with new polymerase chain reaction assay. 7 Sex Transm Dis 1994;21:191-5.

35 Kowalski RP, Uhrin M, Karenchak LM, Sweet RL, Gordon YJ. Evaluation of the polymerase chain reaction test for detecting chlamydial DNA in adult chlamydial conjunctivitis. Ophthalmology 1995;102:1016-9.

36 Jackson R, Morris DJ, Cooper RJ, Bailey AS, Klapper PE, Cleator GM, et al. Multiplex polymerase chain reaction for adenovirus and herpes simplex in eye swabs. $\mathcal{F}$ Virol Methods 1996;56:41-8. 